シンポジウム $1-3$

\title{
痛風発作の分子病態
}

痛風は紀元前から知られていた古の疾患であ る. その後の研究により, 痛風発作は高尿酸血 症により尿酸塩 (monosodium urate monohydrate crystals; MSU) 結晶が関節腔内に析出し, 好中 球の浸潤と活性化を誘導することにより惹起さ れる急性炎症であることが明らかにされた。し かし, 生体内のMSU結晶が炎症を惹起する理由, 析出したMSU結晶の認識機序, 痛風発作の炎症 病態を惹起する分子など, 痛風発作のメカニズ ムの詳細は不明のままであった。近年の免疫 学・炎症学研究の進歩により, MSU結晶は生体 にとってのDanger signalであり, 自然免疫機構が これを認識することによって痛風発作が惹起さ れることが明らかにされた。

\section{1. 痛風発作に関与する分子}

痛風発作にはNLRP3 inflammasome, toll-like receptor (TLR), IL-1 $\beta$ とIL-1受容体（IL-1R）な ぞの自然免疫に関与する分子が主要な役割を担 つている. 自然免疫機構における異物認識には, 細胞内センサーであるNLR（Nucleotide binding oligomerization domain-like receptor) と, 細胞外 センサーであるTLRが機能している. NLRファ ミリーとTLRファミリーに属する分子は，いず れも分子内に異物のパターン認識を担うleucinerich-repeat（LRR）ドメインを持つている. NLR ファミリーの中で, 痛風発作に関与するのは NLRP3 (Nucleotide-binding domain, leucine-richcontaining family, pyrin domain-containing-3) であ
赤星透

る.NLRP3はNALP3またはクリオピリンとも呼 ばれていた分子であり, 細胞質内においてASC (Apoptosis-associated speck-like protein) やprocaspase-1などの分子と共にNLRP3 inflammasomeとよ ばれる分子集団を形成する。 NLRP3 inflammasomeは通常は非活性状態にあるが, 細胞内に異 物が侵入すると活性化され, procaspase-1がcaspase-1に変換されることにより, proIL-1 $\beta$ や proIL-18などのサイトカイン前駆体を成熟型の IL-1 $\beta$, IL18に変換して, 細胞外へと分泌させ る.

現在, NLRP3 inflammasomeを活性化する分子 としては, 細菌由来分子（毒素, フラゲリン, MDPなど), ウイルス由来分子（RNAなど），真 菌由来分子（ $\beta$ グルカン, マンナン, ザイモザ ンなど)，非微生物由来分子（ATP, MSU結晶, コレステロール結晶, アミロイド $\beta$ ，アルミニ ウム，アスベスト）などが報告されている.

一方，TLRは細胞表面に発現する 1 本鎖構造 のパターン認識受容体であり, 細胞外には異物 を認識するleucin-rich repeat ドメイン, 細胞内に はTIR（Toll/interleukin-1receptor）ドメインを持 つ. TLRファミリーには現在 11 種類の分子 （TLR1〜 TLR11）が存在する. 異物を認識した TLRは，同じくTIRドメインを持つMyD 88 (myeloid differentiation factor 88) と会合してシグ ナルを伝達し, 炎症に関連する分子の遺伝子発 現を誘導する。

痛風発作の炎症病態において中心的な役割を 
担うサイトカインはIL-1 $\beta$ である. IL-1 $\beta$ が結合 しシグナルを伝達する受容体であるIL-1R I は, TLRと構造が類似し, 細胞内にはTIRドメインを 持っている。IL-1がIL-1R I に結合すると， MyD88 と会合することによりシグナルを細胞内 に伝達する。

\section{2. 痛風発作の分子メカニズム}

2006年に, MSU結晶がNLRP3 inflammasomeの 活性化を介して IL-1 $\beta$ 産生を誘導すること, MSU結晶による急性炎症の発現にはIL-1Rが必須 であることが報告された。MSU結晶は食食細胞 に貪食され，ライソゾーム内に取り込まれる. 次いで, ライソゾームが障害されることにより, MSU結晶, カテプシンなどが細胞質内に放出さ れ，活性酸素の産生も誘導される。さらに, MSU結晶による細胞障害により細胞外に放出さ れたATPはP2X7Rを介して細胞内のKイオン濃度 を低下させる。 MSU結晶, カテプシン, 活性酸 素, Kイオン濃度の低下などはNLRP3 inflammasomeを活性化させてcaspase-1を誘導し, IL-1 $\beta$ 前 駆体を成熟型のIL-1 $\beta$ に変換して細胞外へと分泌 させる。分泌されたIL-1 $\beta$ は autocrineまたは paracrine機序によりIL-1Rに結合し, さまざまな 炎症関連分子の遺伝子発現を誘導する.

痛風発作におけるTLRの関与については, 相 反する結果を示す論文があり, 論議の対象とな っていた。 Liu-Bryanらは, マウス骨髄由来 $\mathrm{M} \psi$ によるMSU結晶食食とマウス皮下空気囊胞に MSU結晶を注入することにより誘発される好中 球浸潤とサイトカイン産生にはTLR2, TLR4, MyD88が必須であることを2005年に発表した。 一方, Chen らはMSU結晶誘発性マウス腹膜炎モ デルにおける好中球浸潤とサイトカイン産生に は, IL-1とIL-1Rが必須であり，TLRは関与しな いことを2006年に発表した。この相反する結果 の理由の詳細は不明であつたが, 2010 年の Joosten らの報告により, 部分的な理解が得られ た. Joosten らは, MSU結晶と遊離脂肪酸のヒト 末梢血単核球への添加培養, ならびにMSU結晶 と遊離脂肪酸のマウス関節腔内への注入は,
TLR2 とinflammasomeを介してIL-1 $\beta$ の産生と関 節炎を誘導することを明らかにし, MSU結晶自 体にはIL-1 $\beta$ 産生誘導能はないが, TLR2 と遊離 脂肪酸 $(\mathrm{C} 18: 0)$ の存在により, inflammasomeを 介するIL-1 $\beta$ 産生が誘導され, 関節炎が惹起され ることを報告している，従来より，生体内にお いて析出したMSU結晶の表面には脂肪成分や蛋 白成分が付着し, 特に脂肪成分が結晶の炎症誘 発能に影響を与えることが知られていた。ささら に, NLRP3 inflammasomeによるIL-1 $\beta$ 産生誘導 において, IL-1 $\beta$ 遺伝子の発現を誘導する priming メカニズムが不明であるとの指摘もあった. MSU結晶と遊離脂肪酸自体にはTLRへの直接作 用はないが，MSU結晶と遊離脂肪酸を共存させ ると, おそらくは遊離脂肪酸が結晶表面に付着 することにより danger signalへと変化し，TLR2に 認識されてIL-1 $\beta$ 遺伝子発現が誘導され, 次いで NLRP3 inflammasomeの活性化により成熟型IL-1 $\beta$ の分泌が誘導されることにより, 痛風発作が 惹起されるものと推測されている.

さらに，私どもはMSU結晶をマウス腹腔 M $\psi$ に添加すると, M $\psi$ 表面にtriggering receptor expressed on myeloid cells 1 (TREM-1) と呼称さ れる, 自然免疫に関連した受容体の発現が充進 し, TREM-1刺激はサイトカイン産生を誘導する ことを報告した。TREM-1のリガンドは未だ不明 であるが，TREM-1を介する刺激はTLRの作用を 相乗的に増強させることが知られており, 痛風 発作にもTREM-1が何らかの役割を担っているも のと推測される.

\section{3. 痛風に対するIL-1制御療法}

現在，IL-1抑制に用いられている分子には，リ コンビナントIL-1RaであるAnakinra, IL-1R I と IL-1RAcPの細胞外ドメインにIgG1のFc部分を結 合させたdimeric fusion proteinであるRilonacept (IL-1 Trap), 完全ヒト型化抗IL-1 $\beta$ モノクローナ ル抗体であるCanakinumabの3種類がある. 現在, 痛風発作患者や治療抵抗性の痛風患者などを対 象としたIL-1 $\beta$ 制御療法が世界的に試夕られ，い ずれも有効であることが確認されている. 


\section{4. 生体におけるdanger signalの意義}

ヒト血清中には多量の尿酸が存在している. この尿酸が結晶化すると炎症反応を惹起させる ことから，MSU結晶は生体にとって内因性の danger signalであると考えられる，さらに，MSU 結晶は痛風だけではなく, adaptive immunityにお いてもアジュバントとして免疫反応を賦活化さ せることが報告されている。生体内のさまざま
な分子 (HMGB1やATP, modified LDL, 熱ショ ック蛋白質など）もdanger signalとして作用する ことが報告されている，今後，Danger signalに関 する研究が進歩することにより，原因や病態が 不明であった多くの炎症性疾患の病因・病態が 解明され，新たな治療法が開発されることが期 待されている. 